\title{
Aikuiskasvatuksen keskuksia ja reunamia
}

\author{
Kristiina Brunila \& Ulpukka Isopahkala-Bouret (toim.) Marginaalin voima! \\ Aikuiskasvatuksen 51.vuosikirja. Helsinki: Kansanvalistusseura ja \\ Aikuiskasvatuksen tutkimusseura. 2014. 244 s. \\ ISBN 978-951-9140-70-4.
}

AIKUISKASVATUKSEN 51. vuosikirja Marginaalin voima! on kokoelma eri tieteenaloja edustavien tutkijoiden näkemyksiä marginaalista kulttuurisesti tuotettuna erontekona. Teoksen ovat toimittaneet Kristiina Brunila ja Ulpukka Isopahkala-Bouret, jotka ovat itse tutkineet monenlaisia marginaaleja ja marginalisaatiota ilmiönä. Muut kirjoittajat ovat tutkijoita eri tieteenaloilta.

Marginaalin voima! piirtää aikuiskasvatuksesta kuvan monitieteisenä kenttänä, jossa ei rakenneta raja-aitoja perinteisten oppiainejakojen mukaan. Aikuiskasvatustieteessä on tilaa monenlaisille äänille, olivat ne sitten marginaalissa, keskustassa tai jossain niiden välillä. Koska teos keskittyy marginaalien tarkasteluun, näyttää aikuiskasvatus sen valossa kriittisemmältä kuin se ehkä onkaan.

Teos alkaa toimittajien kirjoittamalla johdannolla, jonka jälkeen kirja jakautuu kolmeen osaan. Johdannossa toimittajat pohtivat aikuiskasvatuksen suhdetta marginaaliin. Aikuiskasvatuksellakin on rooli marginalisaation prosesseissa: aikuiskasvatus on pyrkinyt ehkäisemään marginalisoitumista ja auttamaan marginaalissa olevia osaksi valtavirtaa, mutta samalla se on osin tahtomattaan ollut luomassa marginaaleja ja asettamassa yksilöitä niihin.

Myös aikuiskasvatuksen itsensä voi sijoittaa erilaisiin marginaaleihin tieteen ja tutkimuksen hierarkioissa, ja aikuiskasvatuksen sisällä on erilaisia keskuksia ja marginaaleja, jotka ovat jännitteisessä suhteessa toisiinsa. Toimittajat näkevät nämä marginaalit aikuiskasvatuksen voimana, uuden tiedon, luovuuden, inspiraation ja kriittisen tutkimuksen lähteinä.

Teoksenensimmäisessä artikkelissa Siltoja yli valtavirran toimittajat Brunila ja Isopahkala-Bouret jatkavat johdantoartikkelin tematiikkaa tarkastelemalla teoreettisia ja metodologisia näkökulmia marginaalin tutkimiseen aikuiskasvatuksessa.

He itse ymmärtävät marginaalin ennen kaikkea foucault'laisen vallan ja hallinnan käsitteiden kautta, jolloin marginaalissa oleminen nähdään yhtältä toimijuutta rajoittavaksi, toisaalta mahdollistavaksi. Kirjoittajat muistuttavat myös, että puhuttaessa marginaaleista puhutaan samalla siitä, mitä vasten marginaali rakentuu ja minkä ylläpitämiseen marginaalia tarvitaan. Siksi analysoitaessa marginaaleja tulisi katse kohdistaa myös keskuksiin.

Leena Koski tekee juuri tämän artikkelissaan Minä ja maailma aikuiskasvatuksen keskuksessa. Hän sijoittaa aikuiskasvatuksen keskiöön pyrkimyksen ihmisen sisäisyyden löytämiseen, ymmärtämiseen ja muokkaamiseen. Se, mikä kulloinkin ymmärretään sisäisyydeksi ja ihmisen olemukseksi vaihtelee ajassa ja paikassa, mutta tämä pyrkimys säilyy aikuiskasvatuksen ytimessä.

Ensimmäisen osan päättää Karin Filanderin ja Sanna Ryynäsen aikuiskasvatusta ja sosiaalipedagogiikkaa valtavirtojen haastajina käsittelevä artikkeli Aikuiskasvatus ja sosiaalipedagogiikka valtavirtojen haastajina. Kirjoittajat toteavat aikuiskasvatuksen olevan risteyskohdassa: elinikäisen oppimisen diskurssi on valjastettu kansal- 


\section{KUN KIELTÄYDYTÄÄN TIUKOISTA}

\section{MÄ̈ITELMISTÄ, VOIDAAN}

\author{
SAMALLA NOSTAA ESIIN ILMIÖN \\ MONITULKINTAISUUS.
}

lisen kilpailukyvyn edistämisen tavoitteisiin, mikä on hämärtänyt aikuiskasvatuksen suhdetta sen sivistyksellisiin ja tasa-arvoisuutta lisääviin kriittisiin arvolähtökohtiin.

Siksi juuri nyt olisi aika arvioida uudelleen elinikäisen oppimisen ja kasvatuksen politiikkapuheen ja talouspuheen keskeiset lähtökohdat kestävän kehityksen ja kasvun näkökulmasta. Tämä saattaa kirjoittajien mukaan toteutua parhaiten tietoisesti tutkimuksen marginaaleissa pysytellen.

Teoksen toinen osa, Koulutus ja työelämä marginaalin paikantajina, koostuu neljästä artikkelista. Antti Teittinen käsittelee kirjoituksessaan vammaisten asemaa ja oikeuksia suhteessa koulutukseen ja työllistymiseen. Heikki Silvennoinen ja Hanna Nori tarkastelevat oppimis- ja koulutusmahdollisuuksien jakautumista suomalaisessa työelämässä ja etenkin niitä työntekijöitä, joilla nuo mahdollisuudet ovat heikoimmat.
Seija Keskitalo-Foley puolestaan pohtii lappilaisten naisten toimijuutta. Hän kyseenalaistaa marginaalin käsitteen negatiivisen leiman tuomalla esiin kaksinkertaisesti (sukupuolensa ja lappilaisuutensa takia) marginalisoitujen informanttiensa tavat tuottaa feminististä vastapuhetta. Sillä vastustetaan kulttuurisesti vallitsevia kategorisointeja esimerkiksi Lapista etäisenä ja eksoottisena määrittelemällä se arkiseksi oman elämän keskukseksi.

Niina Viitasalo tarkastelee ikäsyrjinnän takia työmarkkinoiden marginaaliin joutuneiden varttuneiden työttömien toimijuutta. Viitasalo luonnehtii työttömien toimijuutta tukahtuneeksi: he yrittävät aktiivisesti palata työmarkkinoille, mutta yritykset epäonnistuvat toistuvasti, minkä seurauksena työllistymisyrityksiin ja työhön ladattu toivo ja energia hiipuvat. Elinikäisen oppimisen tavoitteeseen sisältyvä aktiivinen toimijuus ei yksin riitä työllistymiseen liittyvien tavoitteiden toteutumiseen työmarkkinoil- la, joilla on ikäsyrjintää. Katseen kohdistaminen vain yksilöihin kääntää yhteiskunnalliset epäkohdat yksilön ongelmiksi.

Viitasalo tekee saman kiinnostavan havainnon kuin Filander ja Ryynänen aiemmin kuvatussa artikkelissaan: elinikäisen oppimisen diskurssi voi itsessään tuottaa ja uusintaa marginaaleja.

Kirjan kolmas ja viimeinen osio, Marginaali toisin tekemisenä, muodostuu kolmesta artikkelista, jotka kuvaavat tavalla tai toisella marginaalissa olemista valintana. Sinikka Pesonen tarkastelee ekoyhteisöjä, jonka jäsenet elävät vapaaehtoisesti kulutusyhteiskunnan näkökulmasta katsottuna marginaalissa, ja Johanna Aromaa esteettömän tanssin opettajia, jotka hyödyntävät työssään marginaaliin sijoitettua tiedon muotoa, ruumiillista tietoa.

Teoksen päättää Elina Ikävalkon ja Tuuli Kurjen artikkeli nomadisesta, kuljeskelevasta tutkimuksesta ja kirjoittamisesta, joka on tieteen tekemisen tapana kokeilevaa ja toiminnan välineellistymistä pakenevaa.

Osa artikkeleista olisi kaivannut tiukempaa toimitustyötä, sillä niissä oli paikoin toistoa ja tiivistämisen varaa. Teos kärsii myös monitieteisille artikkelikokoelmille tyypillisistä ongelmista: 
artikkelit eivät aina kohtaa käsitteellisesti, ja joissakin artikkeleissa yhteys aikuiskasvatukseen on melko ohut.

Tulkintojen moniäänisyyden voi kuitenkin nähdä myös teoksen rikkautena, joka mahdollistaa vaihtoehtoisia tiedon tuottamisen tapoja. Kun kieltäydytään tiukoista määritelmistä, voidaan samalla nostaa esiin ilmiön monitulkintaisuus.

Teoksen vahvuus on, että vaikka marginalisaatio ilmiönä tuottaa monenlaisia ulossulkemisia, eivät artikkelit uusinna kurjuuspuhetta. Niissä tuodaan esiin asioita, joita marginaalissa oleminen mahdollistaa. Jotkut valitsevat marginaalin vapaaehtoisesti, ja usein nekin, jotka ovat marginaalissa vastoin tahtoaan, onnistuvat löytämään tiloja omaehtoiselle toimijuudelle. Silti teoksessa ei sorruta ihannoimaan marginaalia, vaan otetaan huomioon myös sen toimintamahdollisuuksia rajoittava merkitys.

Marginaalin voima! haastaa aikuiskasvatuksen kentän toimijat oman toimintansa kriittisempään tarkasteluun. Tarkasteltaessa marginaalia kulttuurisesti tuotettuna erontekona avautuu samalla mahdollisuus kyseenalaistamiseen ja muutokseen. Marginaalin voima! -teosta voikin suositella kaikille aikuiskasvatuksen nykytilasta kiinnostuneille.

Hanna Ylöstalo

YTT, aikuiskasvatuksen

yliopistonlehtori

Kasvatustieteiden yksikkö

Tampereen yliopisto 